\title{
EVALUATION OF THE USEFULNESS OF SELECTED COMPUTER PROGRAMS IN THE CONTEXT OF EDUCATING STUDENTS OF THE ENVIRONMENTAL ENGINEERING
}

\author{
OCENA UŻYTECZNOŚCI WYBRANYCH \\ PROGRAMÓW KOMPUTEROWYCH W KONTEKŚCIE \\ KSZTAŁCENIA STUDENTÓW INŻYNIERII ŚRODOWISKA
}

\begin{abstract}
The article presents the evaluation of usefulness of selected computer applications applied in the process of educating students from ordered specialty Environmental Engineering who study at the Silesian University of Technology in the faculty of Energy and Environmental Engineering. The evaluation was carried out by means of the analysis of questionnaires filled in by the graduates of the first cycle degree programme at the aforementioned specialty. The analysis was carried out for both, the area of application of the selected software related to the didactic process and the area of the software application in the predicted professional career of the students surveyed.
\end{abstract}

Keywords: environmental engineering, educational process, computer programs, questionnaire form, ranking of the software

\section{Introduction}

Per definition, Environmental Engineering is one of the disciplines of technical sciences which covers the engineering undertakings that aim at preservation of natural environment in balanced condition and at preservation of its possibility to self-regenerate and self-purification and in case of environment devastation ( $e g$ as a result of too intensive economic activity) the undertakings which aim at restoring the balance. Environment engineering deals with such human actions in the environment as broadly defined construction, agriculture and industrial activity. It covers many various tasks related to water treatment, sewage treatment, waste treatment, water supply and sewage drainage, heating and air conditioning, air protection, environment monitoring and protection (ecological engineering) and many other [1-3]. Studies at Environment Engineering faculty are of technical and technical and natural character. The graduates of the field of study gain knowledge which gives the basis for solving technical, technological and organizational

\footnotetext{
${ }^{1}$ Institute of Water and Wastewater Engineering, Silesian University of Technology, ul. S. Konarskiego 18, 44-100 Gliwice, Poland, phone 32237 16 98, fax 3223710 47, email: swiatoslaw.krzeszowski@polsl.pl
} 
problems related to protection, use and transformation of natural resources - both in the external and internal environment (micro-climate, installations in the buildings). As a graduate of technical studies, such a person is also prepared to realize design, performance, exploitation, repair and construction as well as production and trade works in terms of environment engineering in all the domains of economy and administration.

It is commonly known that modern and effective engineering practice in all engineering domains, including Environment Engineering is not possible without the support from computer systems and applications. The number of programs available on the market used for the purposes of supporting the above aspects of environment engineers activity is very high, as far as software of both, narrow and wide spectrum of application is concerned.

The herein paper is to present the evaluation of programs selected by the students with regard to their didactic application during the studies and the predicted practical applications during possible professional career in Environment engineering. The evaluation was carried out with the use of surveys among students who graduated from engineering studies in 2014 with ordered specialty of Environment Engineering at the Faculty of Environment Engineering and Power at the Silesian University of Technology. The students in the course of studies were able to familiarize with all the computer programs evaluated in terms of the research. Based on the survey results the usefulness of selected computer programs in didactic process was assessed. It has to be underlined that courses related to the use of software evaluated in the questionnaire took place in the early phase of the studies during the 2 nd term of the engineering studies.

\section{Materials and methods}

A paper survey was used as a research tool. The survey was filled in by a group of 30 students - the graduates of the first cycle degree programme of Environment engineering. There were 10 computer programs evaluated in the survey. The programs were separately evaluated in two areas of application: 1. during the didactic process (studies), 2. during the, predicted by students, professional career. The total score covered scores in all categories in terms of the given area of application, the maximum value of which was 100 and it was used for the purposes of preparing the rating of the evaluated software. The scheme of evaluation categories applied for each of the application areas with the scales of component grades (category levels) is presented in Table 1 .

The scheme of evaluation categories with the scales of component grades contained in the survey on the usefulness of selected computer programs

\begin{tabular}{|c|c|c|c|c|}
\hline \multicolumn{6}{|c|}{ The area of didactic applications (in the course of studies) } & Uccessibility of \\
\hline Category of evaluation $\rightarrow$ & Practicability & $\begin{array}{c}\text { Widening of } \\
\text { knowledge } \\
\text { didactic version }\end{array}$ & Universality \\
\hline $\begin{array}{c}\text { Marking scale in the given } \\
\text { category } \rightarrow\end{array}$ & $0-40$ points & $0-25$ points & $0-15$ points & $0-20$ points \\
\hline \multicolumn{2}{|c|}{ The area of predicted by students professional careers } & \\
\hline $\begin{array}{c}\text { Category of evaluation } \rightarrow \\
\text { Marking scale in the given } \\
\text { category } \rightarrow\end{array}$ & Practicability & Innovation & $\begin{array}{c}\text { Simplicity of the } \\
\text { use }\end{array}$ & Universality \\
\hline
\end{tabular}


The list of assessed programs, ordered alphabetically according to the name, along with their short description was presented below:

1. AquaChem - software being used for a management, accumulation, advanced analysis and reporting of groundwater water quality data. It develops a fully customizable database of physical and chemical parameters and a comprehensive selection of analysis, calculation, modeling, and graphing tools. Producer: Schlumberger Water Services [4].

2. AquiferTest - easy-to-use software package for analyzing, interpreting and visualizing pumping and slug test data. This software delivers all the tools needed to accurately interpret data from all types of aquifers in all types of test conditions Producer: Schlumberger Water Services [5].

3. Audytor OZC - software commonly used to aiding design of the thermal and cooling systems. Producer: Sankom Sp. z o.o. [6].

4. AutoCAD - universally well-known and recognised program being used for a widely understood computer-aided design. Producer: Autodesk Inc. [7].

5. BioWin - software being used for a simulation of processes of the sewage treatment. Producer: EnviroSim Associates Ltd. [8].

6. EpaNET - computer application that performs extended-period simulation of the hydraulic and water quality behavior within pressurized pipe networks. Producer: Environmental Protection Agency USA [9].

7. IMSDesign - comprehensive software design program that allows the user to design a membrane system using Hydranautics membranes. Producer: Hydranautics Nitto Group Company [10].

8. Kan $\mathrm{H} 2 \mathrm{O}$ - software used for aiding design of the water and sewer systems. Producer: KAN System KAN-Therm. [11].

9. MathCAD - universally well-known and recognised software being used for solving mathematical and engineering problems. Producer: MathSoft, at present property of PTC, Inc. [12].

10. Profil Koordynator - program being used to generate profiles and site plans of water-sewer networks, as well as gas and thermal net systems. Producer: EPI-Graf [13].

In the survey, apart from the described above part used for the purposes of evaluation of the selected programs, two questions were included which aimed at determination which of the evaluated software should in the respondent's opinion be removed from the course of studies and also which software that is not present on the list of evaluated programs they would want to familiarize with in terms of the didactic process at the first cycle degree programme of Environment engineering.

\section{Results and discussion}

The cumulative results for the area of didactic applications with the software rating prepared based on it are presented in Table 2, while the survey results for the area of applications related to predicted professional career are presented in Table 3.

In the first area of applications, the highest note was received by AutoCAD. It obtained the average note of 96.33 while the maximum number of points to get was 100. Such a high note for the program is understood as it is highly appreciated by most professional users of 
this type of software. Additionally it is commonly used in engineering practice and knowledge on how to operate it is very useful also in case of working with other software applied in Environment engineering, especially with regard to specialties related to designing and servicing of water and sewage systems. The second and the third place in the rating were achieved by Audytor OZC and Profil Koordynator, with the results of 82.58 points and 81.40 points, respectively. These are the programs of greater specialty level than the aforementioned AutoCAD. The programs have also been intensively applied during the didactic courses, especially while designing. It has to be added that Profil Koordynator software created by Polish producer, though being highly specialized software, is commonly recognized by professionals in Environment engineering as one of the best in its class of applications.

Table 2

Partial evaluations and the final rating of selected computer programs for the field of teaching applications

\begin{tabular}{|c|c|c|c|c|c|c|}
\hline & Practicability & $\begin{array}{c}\text { Widening of } \\
\text { knowledge }\end{array}$ & $\begin{array}{c}\text { Accessibility of } \\
\text { didactic version }\end{array}$ & Universality & $\boldsymbol{\Sigma}$ & Final rating \\
\hline AutoCAD & 39.00 & 23.00 & 15.00 & 19.33 & 96.33 & 1. \\
\hline Audytor OZC & 32.86 & 20.91 & 13.24 & 15.57 & 82.58 & 2. \\
\hline $\begin{array}{c}\text { Profil } \\
\text { Koordynator }\end{array}$ & 32.11 & 21.25 & 12.78 & 15.26 & 81.40 & 3. \\
\hline Kan H2O & 23.38 & 20.85 & 11.85 & 11.62 & 67.69 & 4. \\
\hline EpaNET & 22.69 & 19.23 & 11.92 & 12.85 & 66.69 & 5. \\
\hline AquaChem & 16.36 & 16.25 & 10.91 & 9.27 & 52.80 & 6. \\
\hline MathCAD & 17.28 & 14.72 & 9.00 & 11.44 & 52.44 & 7. \\
\hline BioWin & 16.92 & 15.71 & 8.85 & 9.00 & 50.48 & 8. \\
\hline AquiferTest & 15.83 & 15.00 & 10.31 & 8.92 & 50.06 & 9. \\
\hline IMSDesign & 12.50 & 14.38 & 10.13 & 7.13 & 44.13 & 10. \\
\hline
\end{tabular}

Table 3

Partial evaluations and the final rating of selected computer programs for the field of related to predicted professional career

\begin{tabular}{|c|c|c|c|c|c|c|}
\hline & Practicability & Innovation & $\begin{array}{c}\text { Simplicity of } \\
\text { the use }\end{array}$ & Universality & $\boldsymbol{\Sigma}$ & Final rating \\
\hline AutoCAD & 39.50 & 23.00 & 13.67 & 19.67 & 95.83 & 1. \\
\hline $\begin{array}{c}\text { Profil } \\
\text { Koordynator }\end{array}$ & 35.26 & 21.25 & 12.85 & 16.84 & 86.21 & 2. \\
\hline Audytor OZC & 33.33 & 19.86 & 12.27 & 16.43 & 81.90 & 3. \\
\hline EpaNET & 27.69 & 16.07 & 10.36 & 13.08 & 67.20 & 4. \\
\hline Kan H2O & 25.71 & 17.33 & 10.80 & 11.79 & 65.63 & 5. \\
\hline MathCAD & 15.94 & 10.61 & 7.53 & 8.59 & 42.67 & 6. \\
\hline AquiferTest & 13.92 & 12.71 & 7.36 & 7.15 & 41.15 & 7. \\
\hline IMSDesign & 12.63 & 10.11 & 8.56 & 7.63 & 38.92 & 8. \\
\hline AquaChem & 11.45 & 12.17 & 7.42 & 7.82 & 38.86 & 9. \\
\hline BioWin & 13.00 & 9.85 & 7.17 & 6.92 & 36.93 & 10. \\
\hline
\end{tabular}

A low note and what follows, a distant place in the rating, obtained by MathCAD, which is well recognized on the market in its spectrum of application was a real surprise. In the author's opinion, it was caused by the fact that the program was poorly used during 
the didactic course. A similar situation took place in case of Biowin software the assessment of importance of which among the fledgling engineers should be, objectively, much higher. The notes and positions in the rating of other programs conformed to the expectations of the survey authors. The usefulness of such computer applications as AquaChem or AquiferTest is lower due to the fact of applying standards other than Polish ones, low versatility of applications, etc. And often the fact that the applications concern technological processes which are not very popular as in case of IMSDesign is decisive.

In the area of applications related to the predicted by the people surveyed professional career, the computer program which obtained the highest note was again AutoCAD. It got 95.83 points on average out of 100 possible. The only thing that may be surprising in the context of the software evaluation in both areas of application is the fact that its note in the area of didactic applications was higher than in the area of applications in the predicted professional career. However the difference was minimum and at the edge of statistical significance. The second and the third place were again taken by swapped Profil Koordynator and Audytor OZC programs with the results of 86.21 points and 81.90 points, respectively. These computer applications are commonly applied in commercial engineering practice. Additionally they are both intensively used by branch specialists. This is why their high notes and positions in the rating shall be considered as well justified. Places five and six, just like in the previous rating, were taken by EpaNET and Kan $\mathrm{H} 2 \mathrm{O}$ software, also swapped as far as the places in the rating for the area of didactic applications are concerned. It has to be underlined here that the notes of the programs in both areas were very similar and at the edge of statistical significance. The evaluation of both programs, in the area of practical applications, with regard to other software, was considered as adequate in terms of their importance on the software market in Environment Engineering. MathCAD was more appreciated this time by the interviewees as it obtained the sixth position in the rating. However, it got a much lower score than in the area of didactic applications. The effect was observed for all the programs from places 6-10. It may be explained by the fact of poor use of the software in the further course of studies which followed the relatively early classes on using the programs during the didactic process. The effect was the best seen with reference to Biowin which this time closed the rating despite the fact that its area of application is integral with the subject of studies. When comparing the notes obtained by the computer programs from places 6-10 in both areas of application it may be stated that the questioned students quite well differentiated the specifics of application of the given software in the areas. For example the practical aspect for AquiferTest application is essentially greater than the aspect of didactic and scientific applications while for AquaChem it shall be stated that its practical importance, especially in terms of engineering practice in Poland is smaller than its scientific and didactic importance. As it clearly results from the positions taken by the programs in each area of application, it was taken into account in the evaluations of the questioned students.

Apart from the described above ratings, the survey contained two questions. The replies to the first one were to specify which programs from the rating should in the surveyed people's opinion be removed from the didactic process, while the replies to the second one were to indicate which software that is not present in the rating shall be taken into account in the process. Based on the replies, a list of computer applications to be removed and a list of software to be implemented in the didactic process were prepared. 
The lists were as follows:

$\begin{array}{cc}\text { SOFTWARE TO BE REMOVED } \\ \text { Name of the software } & \begin{array}{c}\text { Number } \\ \text { of votes }\end{array} \\ \text { AquaChem } & 5 \\ \text { EpaNET } & 5 \\ \text { BioWin } & 4 \\ \text { AquiferTest } & 2 \\ \text { Audytor OZC } & 1 \\ \text { Kan H2O } & 1 \\ \text { MathCAD } & 1\end{array}$

$\begin{array}{cc}\begin{array}{c}\text { SOFTWARE TO BE IMPLEMENTED } \\ \text { Name of the software }\end{array} & \begin{array}{c}\text { Number } \\ \text { of votes }\end{array} \\ \text { CATIA } & 6 \\ \text { Vent Pack } & 4 \\ \text { Inventor } & 3 \\ \text { Solidworks } & 3 \\ \text { Audytor CO } & 2 \\ \text { Zuzia } & 2 \\ \text { Instal OZC } & 1 \\ \text { Instal Therm } & 1 \\ \text { Microstation } & 1\end{array}$

The results of both ratings prepared based on the survey show, in the author's opinion, without any doubt that the students of Environment Engineering course consider the computer programs which are mostly used for applications related to engineering practice as most useful both with regard to the didactic process and future professional career.

The highest notes were given not only to applications of the wide spectrum of use and recognized position on the market (AutoCAD) but also less popular programs of narrow range of application - Audytor OZC and Profil Koordynator. The common feature of all three programs mentioned is their strong position as far as engineering practice is concerned. The ability to use this type of software obviously increases competitiveness of the operators on the labour market.

Based on the information from the list of programs to be removed from the didactic process it may be concluded that the types of software which in the interviewee's opinion were of poor importance in engineering practice (MathCAD), or were poorly related to Polish standards (AquaChem, AquiferTest) are also considered as less useful both in didactic and predicted by the questioned students professional career.

The list of programs to be implemented in the didactic process shows that the interviewees appreciated the importance of software used for 3D designing and modelling. The area of software application is at present considered as modern. Additionally, the programs are recognized as tools which strongly support the innovation. The fact that information about application of 3D modelling is present in all types of media, including news media is certainly not without significance.

\section{Conclusions}

1. The results of both ratings prepared based on the survey show, in the author's opinion, without any doubt that the students of Environment Engineering course consider the computer programs which are mostly used for applications related to engineering practice as most useful both with regard to the didactic process and future professional career.

2. The highest notes were given not only to applications of the wide spectrum of use and recognized position on the market (AutoCAD) but also less popular software of narrow range of application - Audytor OZC and Profil Koordynator. The common feature of 
all three programs mentioned is their strong position as far as engineering practice is concerned. The ability to use this type of software obviously increases competitiveness of the operators on the labour market.

3. Based on the information from the list of programs to be removed from the didactic process it may be concluded that the types of software which in the interviewee's opinion were of poor importance in engineering practice (MathCAD), or were poorly related to Polish standards (AquaChem, AquiferTest) are also considered as less useful both in didactic and predicted by the questioned students professional career.

4. The list of programs to be implemented in the didactic process shows that the interviewees appreciated the importance of software used for 3D designing and modelling. The area of software application is at present considered as modern. Additionally, the programs are recognized as tools which strongly support the innovation. The fact that information about application of 3D modelling is present in all types of media, including news media is certainly not without significance.

\title{
References
}

[1] Baker RW. Ultrafiltration, in Membrane Technology and Applications, Third Edition, Chichester, UK.: John Wiley \& Sons, Ltd; 2012. DOI: 10.1002/9781118359686.ch6

[2] Zarzycki R, Imbierowicz M., Stelmachowski M. Wprowadzenie do inżynierii i ochrony środowiska. (Introduction to environmental engineering and protection). Warszawa: Wyd. Nauk-Techn; 2007.

[3] Rapantova N, Krzeszowski Ś, Grmela A, Wolkersdorfer C. Quantitative assessment of mine water sources based on the general mixing equation and multivariate statistics. Mine Water Environ. 2012;31(4):252-265. DOI: 10.1007/s10230-012-0192-6.

[4] http://www.gambit.nazwa.pl/sws/?aquachem,157.

[5] http://www.gambit.nazwa.pl/sws/?aquifertest,158.

[6] http://pl.sankom.net/programy/audytor-ozc.

[7] http://www.autodesk.com/products/autocad/overview.

[8] http://envirosim.com/products/biowin.

[9] http://www.epa.gov/nrmrl/wswrd/dw/epanet.html.

[10] http://imsdesign.software.informer.com/.

[11] http://pl.kan-therm.com/download/programy_do_projektowania/kan_h2o.html.

[12] http://www.ptc.com/product/mathcad.

[13] http://wersja7.epi-graf.com.pl/profilkoordynator.htm.

\section{OCENA UŻYTECZNOŚCI WYBRANYCH PROGRAMÓW KOMPUTEROWYCH W KONTEKŚCIE KSZTAŁCENIA STUDENTÓW INŻYNIERII ŚRODOWISKA}

\author{
Instytut Inżynierii Wody i Ścieków, Politechnika Śląska, Gliwice
}

\begin{abstract}
Abstrakt: W artykule przedstawiono ocenę przydatności wybranych programów komputerowych zastosowanych w procesie kształcenia studentów kierunku zamawianego inżynieria środowiska studiujących na Wydziale Inżynierii Środowiska i Energetyki Politechniki Śląskiej. Ocenę przeprowadzono poprzez analizę ankiet wypełnionych przez absolwentów studiów I stopnia ww. kierunku. Przeprowadzono analizę zarówno dla obszaru zastosowań wybranych programów związanego z procesem dydaktycznym, jak i dla obszaru zastosowań tego oprogramowania w prognozowanej karierze zawodowej ankietowanych studentów.
\end{abstract}

Słowa kluczowe: inżynieria środowiska, proces dydaktyczny, programy komputerowe, ankieta, ranking oprogramowania 